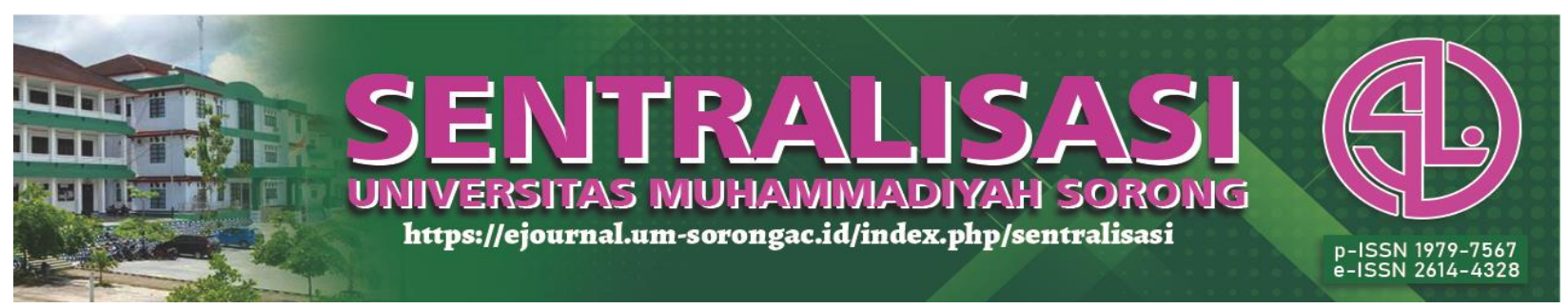

\title{
Application of Quick Response Code Indonesian as a Payment Tool in Digitizing MSMEs
}

\author{
Desy Tri Anggarini \\ Universitas Bina Sarana Informatika, Indonesia \\ E-mail: *desy.dra@bsi.ac.id \\ * corresponding author
}

direvisi: 09/11/2021 dipublikasikan: 08/01/2022

\begin{abstract}
Abstrak. Tujuan dari penelitian memberikan kontribusi pada berkembangnya teknologi dalam bidang finansial memberikan pengaruh bagi masyarakat dalam hal masyarakat tanpa uang tunai atau cashless, selanjutnya juga memberikan wawasan mengenai finansial teknnologi terhadap literasi keuangan dengan pemakaian QRIS (Quick Response Code Indonesian). Pelaku UMKM dapat memudahkan kegiatan usahanya dengan penerapan fintech dalam hal pengelolaan transaksi dan peranan financial technology yaitu aplikasi QRIS (Quick Response Code Indonesian) sebagai alat pembayaran. Metode penelitian yang digunakan pada penelitian Penerapan QRIS (Quick Response Code Indonesian) sebagai Alat Pembayaran dalam digitalisasi UMKM adalah penelitian deskriptif kualitatif menggunakan metode penelitian lapangan atau field research. Penelitian ini menggunakan metode wawancara dengan 10 pedagang lapak dan 10 konsumen UMKM yang menggunakan QRIS lokasi penelitian adalah di Pasar Modern BSD, menggunakan teknik non-probability. Data primer yang diambil secara langsung dari objek penelitian. Dengan metode pengamatan langsung di Pasar modern BSD, Tangerang Selatan dengan teknik wawancara baik konsumen dan pedangan yang menggunakan QRIS juga dengan data sekunder juga diperoleh dengan melalui berbagai literature. Hasil dari penelitian adalah QRIS sebagai alat pembayaran digital bagi UMKM adalah pembayaran yaitu non-tunai dengan digital menggunakan Gopay,Ovo dan lainnya. QRIS berpotensi memperluas penjualan UMKM, dengan QRIS terjadi peningkatan traffic penjualan secara digital dan penurun dalm uang cash, meminimalisir risiko pembayaran uang palsu, transaksi tercatat secara otomatis, building credit profile bagi bank, mempermudah dalam mendapatkan modal kerja, pembayaran restribusi, tagihan, pembelian barang secara non-tunai secara mudah.
\end{abstract}

Kata kunci: UMKM, Digitalisasi, Financial Technology, QRIS

\begin{abstract}
The purpose of the research is to contribute to the development of technology in the financial sector, to give influence to the community in terms of cashless, then also to provide insight into financial technology on financial literacy by using QRIS (Quick Response Code Indonesian). MSME use facilitate their business activities by implementing fintech in terms of transaction management and the role of financial technology, is the QRIS (Quick Response Code Indonesian) application as a means of payment. The research method used in the research on the application of QRIS (Quick Response Code Indonesian) as a Payment Tool in digitizing MSMEs is a qualitative descriptive study using field research methods. This study uses interviews with 10 traders and 10 UMKM consumers who use QRIS. The research location is in BSD Modern Market, using non-probability techniques. Primary data taken directly from the object of research. With the direct observation method at the BSD modern market, South Tangerang with interview techniques for both consumers and traders who use QRIS as well as secondary data also obtained through various literatures. The result of the research is that QRIS as a digital payment tool for MSMEs is noncash digital payment using Gopay, Ovo and others. QRIS has the potential to expand MSME sales, with QRIS an increase in digital sales traffic and a decrease in cash, minimizing the risk of paying counterfeit money, automatically recording transactions, building credit profiles for banks, making it easier to get working capital, payment of retribution, bills, purchasing goods in cash easily.
\end{abstract}

Keywords: MSMEs, Digitalization, Financial Technology, QRIS

Desy Tri Anggarini 


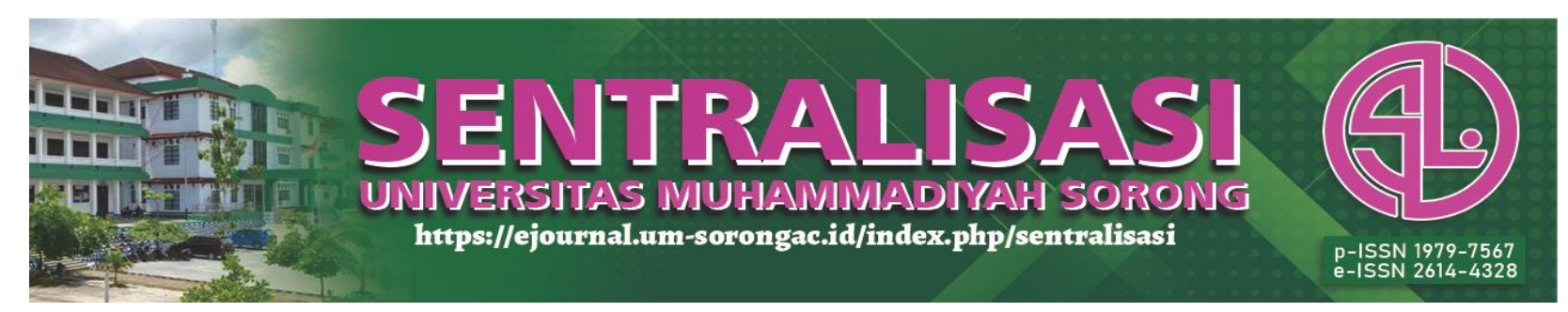

\section{Introduction}

Globalization and innovation in information technology and financial technology have made the financial system more complex, dynamic and connected. E-Commerce can be used to facilitate broad market access. This is supported by an electronic payment method that has become a habit of today's society, which is practically easy and fast. The modern life Financial Technology (Fintech) it is able to make it easier for consumers to make online transactions to MSMEs. (Bank Indonesia, 2021c)

Fintech or financial technology as a financial and technology sector service, where new companies / newcomers can focus on technology and innovation in financial products and services provided by conventional service institutions, so that financial technology is defined as the application and use of technology to improve banking and financial services. (Yarli, 2018). Fintech or financial technology is an innovation in the financial services sector that is very minimal in the use of paper money so that it can be said that financial technology has turned money into digital so that it is more efficient (Hiyanti et al., 2020). Fintech or financial technology explains that it refers to the use of technology and provides solutions related to non-cash finance. (Arner, DW, 2015)

In the era of economic disruption, digitalization is increasingly real and is a strategic step for MSMEs to continue to survive and play a major role in economic recovery.(Kementrian Koperasi dan UKM, 2021) . Paradigm in the financial sector industry because of a disruptive innovation phenomenon. Disruptive innovation is a system transformation innovation from the market that introduces convenience, practicality, accessibility, convenience and more economical costs. This disruptive innovation that takes from certain markets is less attractive to market authorities but the innovation is changeable and able to create new systems(Darma, 2018)

Digital technology currently opens up opportunities for MSMEs to improve business performance as well as contribute to the national economy. MSMEs are industries that have survived in the pandemic era, and have also developed into new sources of strength for the national economy. Bank Indonesia always encourages MSMEs to go digital and is part of the program to increase MSME digitization.(Bank Indonesia, 2021b)

Digitizing payments provides solutions for industrial growth using electronics or what is known as (e-commerce). Financial technology also encourages the growth of new entrepreneurs. Financial technology has enabled the creative industry to reach a wider market distribution. There is an expansion of the market, especially those that have not been served by financial services and conventional banking or the so-called unbanked population.(Wulandari, 2017).

Quick Response Code Indonesian Standard/QRIS is a combination of several QR from Payment System Service Providers with QR Code. QRIS was developed by the industry by the 


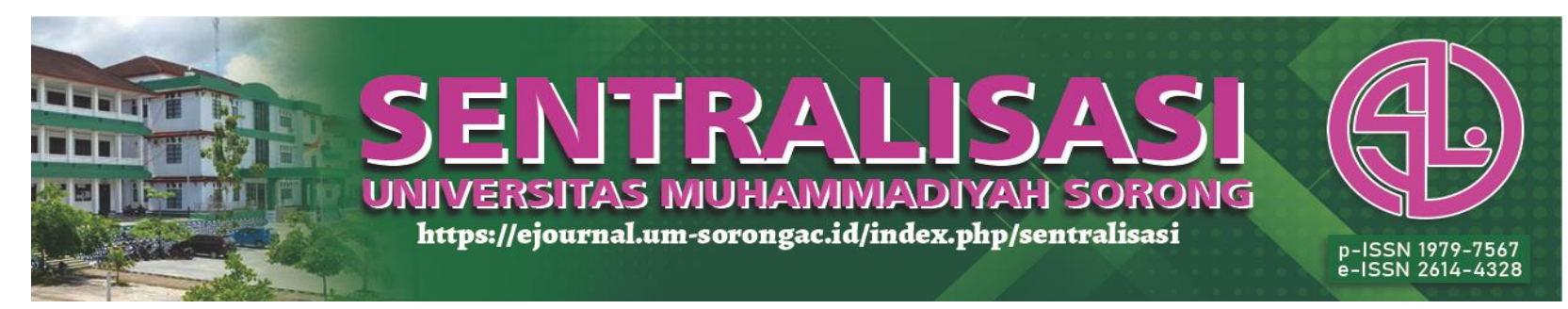

payment system and Bank Indonesia so that the QR Code transaction process can be easier, faster, more practical and more secure in conducting transactions. Payment System Service Providers are required to implement QRIS if they use a QR Code as a means of payment (Bank Indonesia, 2021c). Current financial technology with QRIS, featuring all payment applications from the Operator, both bank and non-bank, can be used at all merchants, shops, parking lots, stalls, tourist tickets, donations (merchants) bearing the QRIS logo.(Bank Indonesia, 2021c)

Bank Indonesia launched the Quick Response (QR) Code standard for payments through electronic money applications, mobile banking, electronic wallets, or the so-called QR Code Indonesian Standard (QRIS). The implementation of QRIS takes effect in early January 2020, during the transition of preparation for Payment System Service Providers/ Jasa Sistem Pembayaran (PJSP). QRIS is the implementation of the Indonesian Payment System (SPI) 2025 launched in May 2019. (Bank Indonesia, 2021c)

QRIS has the motto UNGGUL (Universal, Easy, Profit and Direct), which aims to encourage transaction efficiency, also accelerate financial inclusion, promote MSMEs, and encourage economic growth. (Bank Indonesia, 2021a). QRIS UNGGUL means, First, Universal, the use of QRIS is inclusive for all levels of society and can be used for payment transactions both domestically and abroad. Second, Gampang, people can easily transact safely and securely with their cellphones. Furthermore, Untung means that the QRIS transaction benefits both the buyer and the seller because the transaction takes place efficiently with one QR code that can be used for all payment applications with smart phones, Fourth, Langsung, the process is fast and efficient so as to support the smooth payment system. (Bank Indonesia, 2021b)

The role of the financial industry as well as financial technology as a whole can improve several sectors, to encourage equity and the welfare of the population. Fintech can also help meet the still very large domestic financing needs. On the other hand, fintech encourages the distribution of national financing which is Indonesia is an archipelagic country. Financial technology encourages the growth and ability of exports and MSMEs, which are currently the pillars of the national economy in the pandemic era. There is an increase in national financial inclusion. (Wulandari, 2017).

The four factors in encouraging MSMEs to penetrate the global market are MSMEs must focus on quantity as well as quality and continuity of production, and need to pay attention to product advantages, and prepare and know products that are in demand by the market, domestic or international. MSMEs that need to strengthen institutions and business management. MSMEs improving the mindset in digital competence, and the last MSMEs are studying export procedures, by starting an e-commerce platform and cooperating.

Indonesian MSMEs have the opportunity to participate in international trade and (GVC) Global Value Chain. Based on data from the Ministry of Cooperatives and SMEs, the percentage 


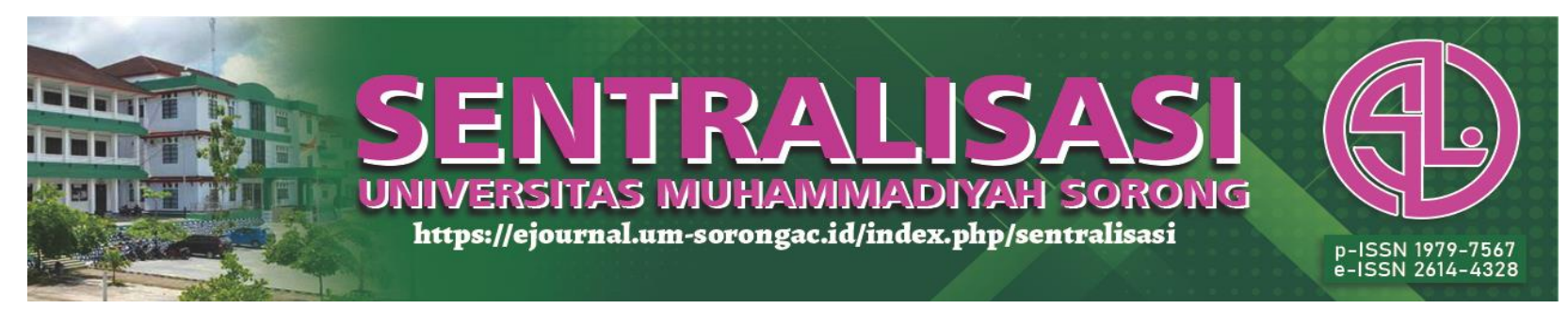

of Indonesian MSMEs reaches $99.9 \%$ of the total number of businesses, MSMEs absorb 97.05\% of workers, and have a GDP contribution of $61 \%$. Bank Indonesia has always encouraged the development of MSMEs as the strength of the Indonesian economy through programs including the digitization of MSMEs, and export-oriented MSMEs. (Bank Indonesia, 2021a)

The Proud National Made in Indonesia (Gerakan Nasional Bangga Buatan Indonesia), is a solution in adapting and transforming in the rise for MSMEs, which has become an acceleration of digital transformation. The revival of MSMEs through synergies that bring together stakeholders, in the last month MSMEs grew rapidly reaching more than 19 percent of the business population or at least 12 million MSMEs.(Paten, 2021)

The digitalization transformation of MSMEs will continue, the Government continues to collaborate for the target of 30 million MSMEs by 2023, and it is hoped that there will be 500,000 MSME digital onboarding products every month, but this is also supported by digital literacy, human resource development, as well as increasing the production capacity and quality of MSME production. (Paten, 2021).

To increase the competitiveness of MSMEs in order to penetrate the global market. The Ministry of Industry to encourage Small and Medium Industries to penetrate the international market, among others through the E-Smart program for Small and Medium Industries from the Ministry of Cooperatives and SMEs and with technological support with a machine and equipment restructuring program, the development of packaging designs, the government also provides technical guidance and guidance an effort to encourage small and medium industries to export, as well as to coordinate with Ministries/Institutions, cooperate with financial institutions, conduct trade promotions and international scale exhibitions. (Bank Indonesia, 2021b)

The development of MSMEs by Bank Indonesia is carried out to support the functions, tasks, and Bank Indonesia in the areas of monetary policy, macroprudential and payment systems. Bank Indonesia which has the authority in the field of monetary policy, macroprudential and payment systems. encourage MSMEs as national economic growth, by formulating a National Strategy (Stranas), that is MSME Development with 3 pillars, namely Corporatization, Capacity and Financing.(Kementrian Koperasi dan UKM, 2021)

The digitization of MSMEs must be supported by two conditions, increasing the capacity of MSME business actors and supporting market access policies for MSME products. For this reason, a joint commitment is needed in providing guidance and assistance to encourage MSME productivity so that they be able to increase production capacity and product quality. Assistance and development of MSMEs with export potential, also supported by facilities and ease of financing.(Kementrian Koperasi dan UKM, 2021)

It was recorded that in 2020 there was an increase in QRIS users to 5.8 million merchants with $84 \%$ of them being micro and small MSMEs. By connecting MSMEs and QRIS payment 


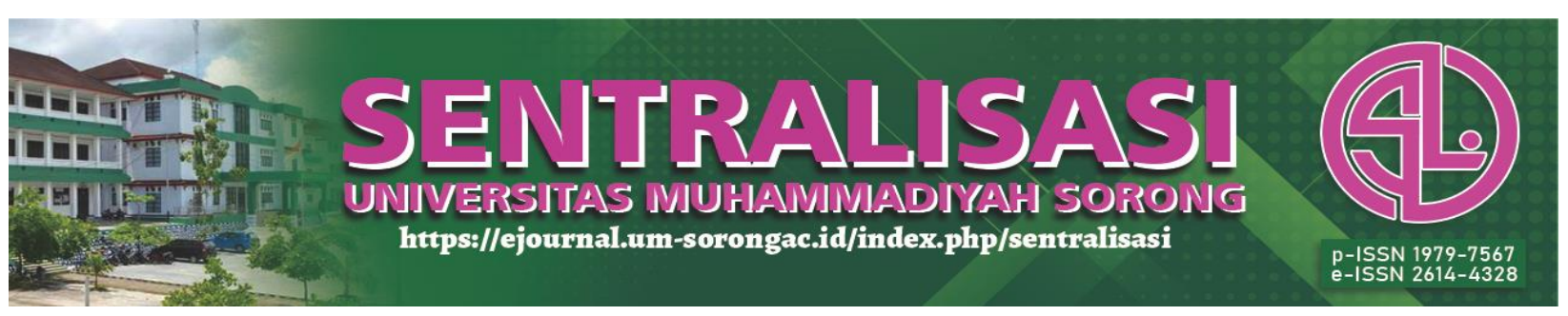

instruments, digitalization of MSMEs is created and supports MSMEs that go digital, go export and become the carrying capacity of the national economy.

Table 1.The Amount of money Outstanding Electronics

\begin{tabular}{cc}
\hline Tahun & Jumlah Intrumen \\
\hline 2015 & 34.314 .795 \\
2016 & 51.204 .580 \\
2017 & 90.003 .848 \\
2018 & 167.205 .578 \\
2019 & 292.299 .320 \\
2020 & 432.281 .380 \\
2021 & 513.968 .693 \\
\hline
\end{tabular}

Source : Bank Indonesia, 2021

The table in 2015 it was still at 34,314,795 and there was a significant increase from 2017 to 2018 then after 2019, every year the money supply increased significantly positively, and in 2021 in August it was recorded at 513,968,693. Non-cash-digital payments for example Ovo, Gopay, LinkAja, Dana, Paytren, CIMB GoMobile, PermataX, MoBRI, Bank Bali and others. So that the potential for sales expansion is due to more practical and efficient payment alternatives.(Bank Indonesia, 2021c).

The application of QRIS (Quick Response Code Indonesian) as a Payment Tool in digitizing MSMEs can improve the Digital Economy and Finance by standardizing the use of QR Codes for non-cash payments to support MSMEs and financial inclusion.

MSMEs use QRIS MSMEs with an annual turnover of Rp. 300 million and assets of Rp. 50 million and Small Business with annual turnover of Rp. 300 million up to Rp. 2.5 billion and assets of Rp. 50 million up to Rp. 500 million, here QRIS expands to street vendors, traditional markets, chain stores, online markets, places of worship and donations, exhibition events and parking lots. (Kementrian Koperasi dan UKM, 2021)

Financial technology is applied to banks, to increase efficiency for service users, this is an initial step for MSMEs that do not have connections, become bigger and develop slowly and as an alternative funding. The lack of innovation in MSME financial technology makes MSMEs less attractive. However, obstacles to implementing financial technology to develop financial inclusion for MSMEs in Indonesia occur due to the lack of MSME financial literacy, then infrastructure, legislation and human resources. (Dalimunthe, 2018)

The partnership between banks and Small and Medium Enterprises will encourage the financial inclusion of MSMEs because Financial Technology enables non-card holder consumers to make payments remotely for the purchase of goods and services.(Gabriella Mulligan, 2015). Technology tools based on Application Programming Interface or (API), have enabled the interaction of two or more services that are connected online, so that they can provide solutions 


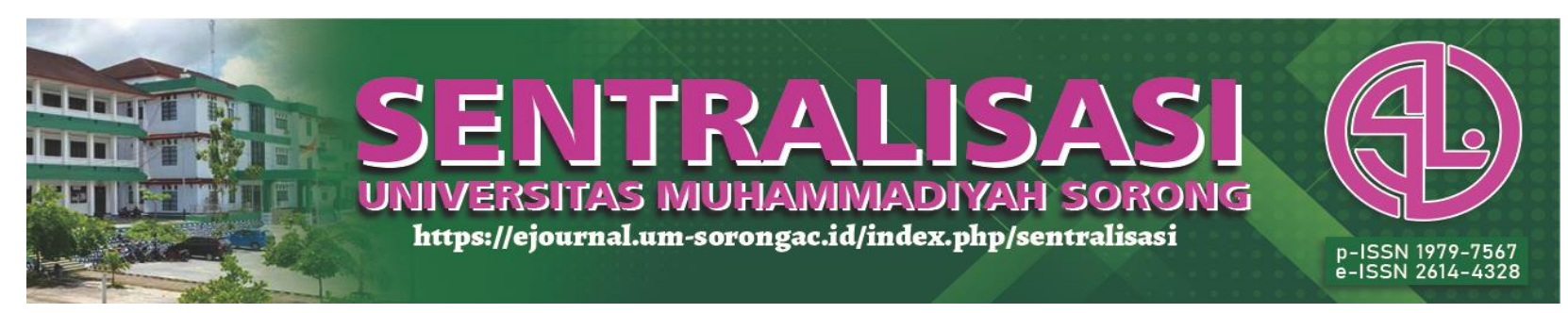

that can be integrated and combined with various services and data sources at the same time, which are operated by one person. (Hasan, 2020)

The purpose of research expected contribute to the development of technology in the financial sector which indirectly an impact of cashless or cashless society, then also provide insight into financial technology on financial literacy, especially the use of QRIS (Quick Response Indonesian Code). MSME facilitating business activities by implementing fintech of transaction management and understanding the role of financial technology, the QRIS (Quick Response Code Indonesian) application as a means of payment for MSMEs in South Tangerang.

\section{Research Methods}

The type of research used in the study of the application of QRIS (Quick Response Code Indonesian) as a Payment Instrument in the digitization of MSMEs is a qualitative descriptive study using field research methods or called field research.(Sugiyono, 2010)

Qualitative method is the method that we apply in this research. According to (Bogdan et.al, 2012) qualitative methods include the results of researchers' observations based on a person's behavior and descriptive data in the form of words, both spoken and written.

Qualitative descriptive research is generally carried out in research in the form of case studies. This social research uses qualitative descriptive which aims to describe, summarize in various conditions, situations, or phenomena of reality that exist in society that are the object of social research, which draws that reality to the surface as a feature, sign, character, model, trait. , or a description of certain conditions, situations, and phenomena. (Bungin, 2011)

The approach used is a case study approach. The case study approach is an approach that uses in interpreting the conditions or circumstances of the research object. This approach is aimed at interpreting and describing the object under study. (Sugiono., 2019)

This study uses interviews with 10 merchant traders and 10 MSME consumers who use QRIS for non-cash payments at shops or market stalls. The research location is in the BSD Modern Market, here the author uses a non-probability technique for data collection and the researcher has prepared a list of questions posed to informants.

The time in the research is for approximately 2 months, from August to September 2021, and the place for the implementation of this research is at the BSD Modern Market, South Tangerang.

Primary data is data obtained directly by researchers from the object of research. Primary data is data that has been collected and processed by the issuing organization or user (Sugiono, 2016). With the direct observation method at the BSD modern market, South Tangerang with interview techniques with stall owners in the market, who use QRIS (Quick Response Code Indonesian) as a digital payment tool, as well as with consumers who use digital transactions at 


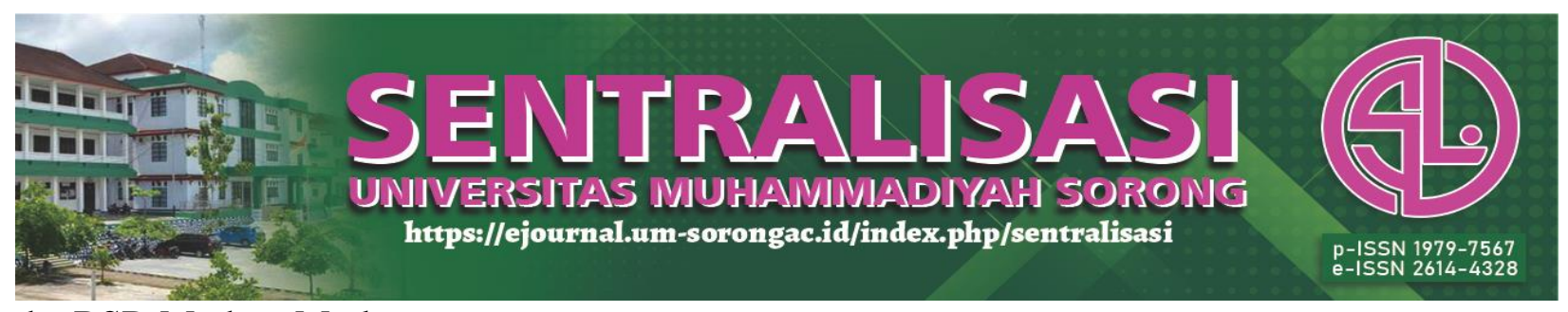

the BSD Modern Market.

Secondary data is also obtained through various literature (Sugiono, 2016) from agencies such as Bank Indonesia, the Ministry of Cooperatives and Small and Medium Enterprises, books, from relevant scientific journals and print or electronic mass media, regarding the development of fintech through the QR Code Indonesian Standard. or known as QRIS.

\section{Results and Discussion}

\section{Results}

According Neurosensum Research, people are used to using digital wallets, people prefer to use digital wallets and gradually begin to replace cash. The use of digital wallets from November 2020 to January 2021, this research shows that there are 5 largest digital wallets in Indonesia, namely Shopeepay with $68 \%$ penetration, the highest compared to other wallets, then the second position is OVO with $62 \%$ penetration then in position Third, DANA has a $54 \%$ penetration. In the fourth position, GOPAY has a penetration of $53 \%$ and the last fifth is LINK Aja, a state-owned digital wallet with a penetration of $23 \%$.

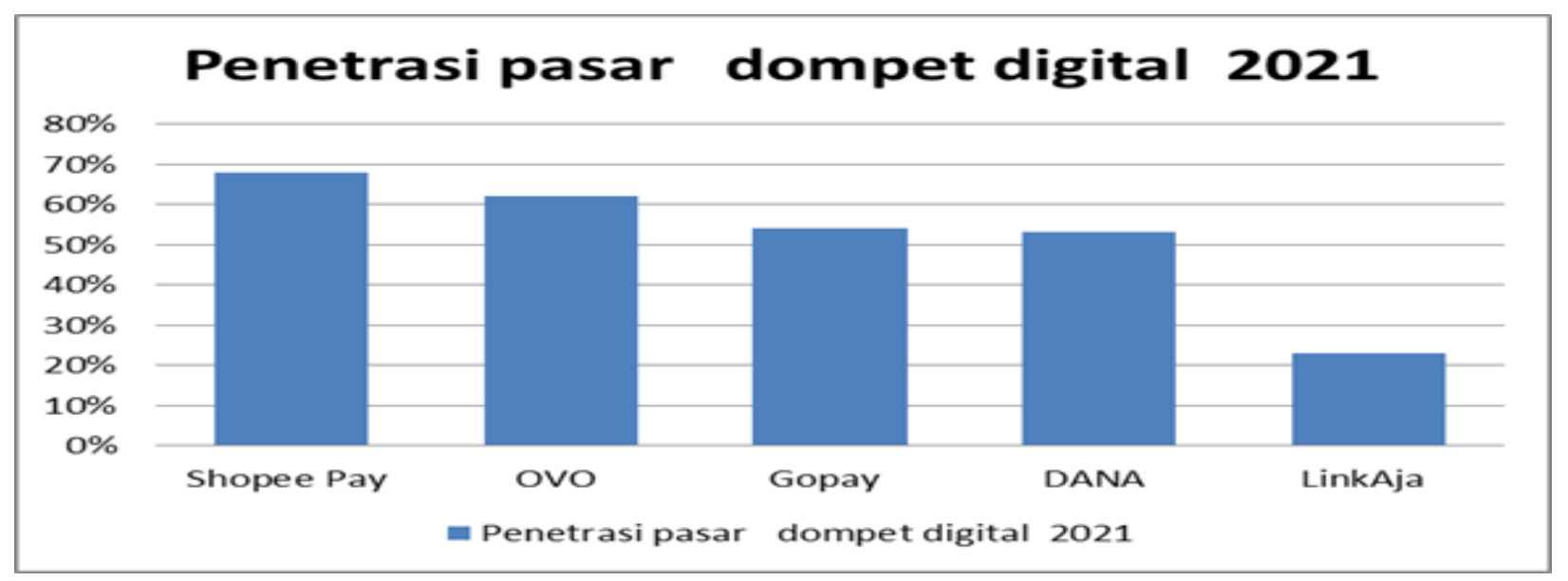

Source: Neurosensum, 2021

Figure 1. The Largest Digital E-Wallet Market Penetration in Indonesia

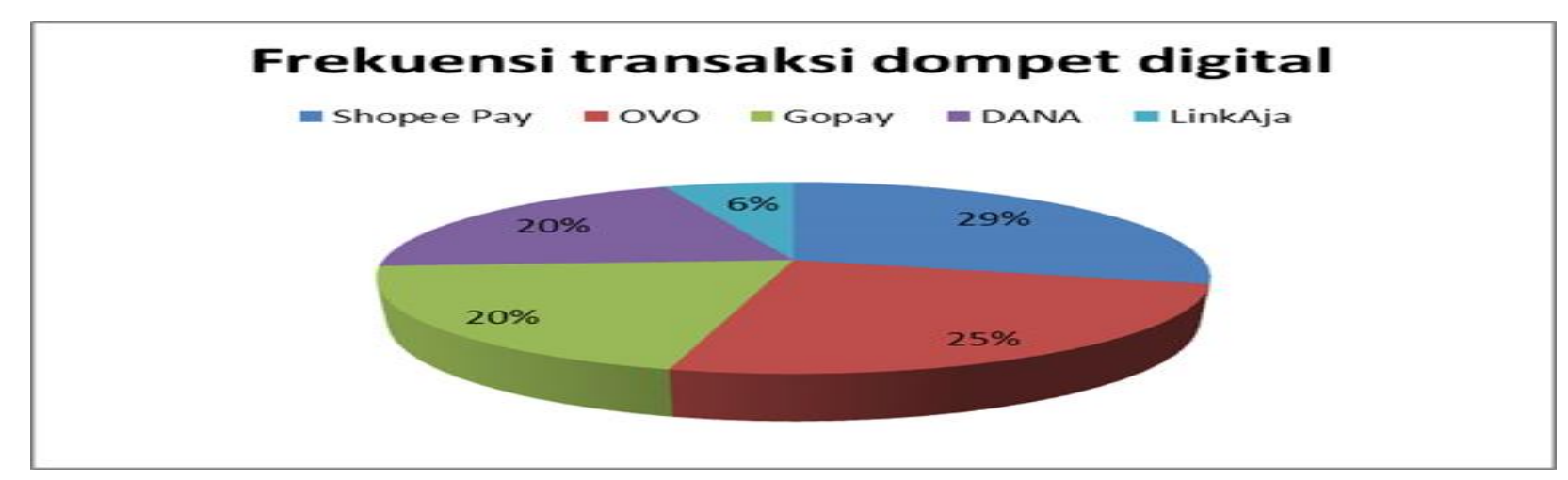

Source : Neurosensum, 2021

Figure 2. Digital e- wallet transaction frequency

Desy Tri Anggarini 


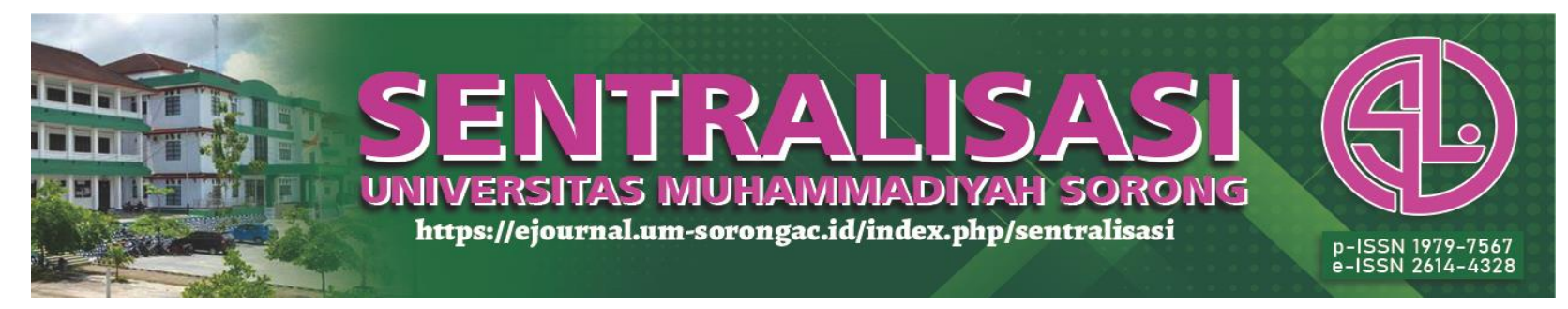

From the graph Figure 1 states that digital transactions and the ease of using digital wallets or non-cash payments are considered by consumers using the ShopeePay digital wallet to make the highest transaction $29 \%$, then the OVO digital wallet, which is to make $25 \%$ transactions. , and the fourth position is FUND with a transaction frequency of $20 \%$ and the last is DANA, which is $6 \%$.

Table 2. The Transaction of frequency per month by digital e- wallet

\begin{tabular}{lc}
\hline Dompet Digital & Frekuensi \\
\hline Shopee pay & $14.4 \%$ \\
Ovo & $13.5 \%$ \\
Gopay & $13.1 \%$ \\
Dana & $12.2 \%$ \\
Link Aja & $8.2 \%$ \\
\hline
\end{tabular}

Source : Neurosensum, 2021

The transaction frequency on ShopeePay is the highest transaction, that is 14.4 times per month, then the second position is OVO 13.5 times per month, then the GoPay digital wallet is 13.1 times per month, the fourth position is DANA 12.2 times per month and lastly LinkAja 8.2 times per month. (Neurosensum, 2021) stated that digital wallets are an innovation and a cashless lifestyle and digital wallets are increasingly in demand by the public today.

There are 2 types of QRIS on Merchant issued by Bank Indonesia, (1) Static QR Code and (2) Dynamic QR Code

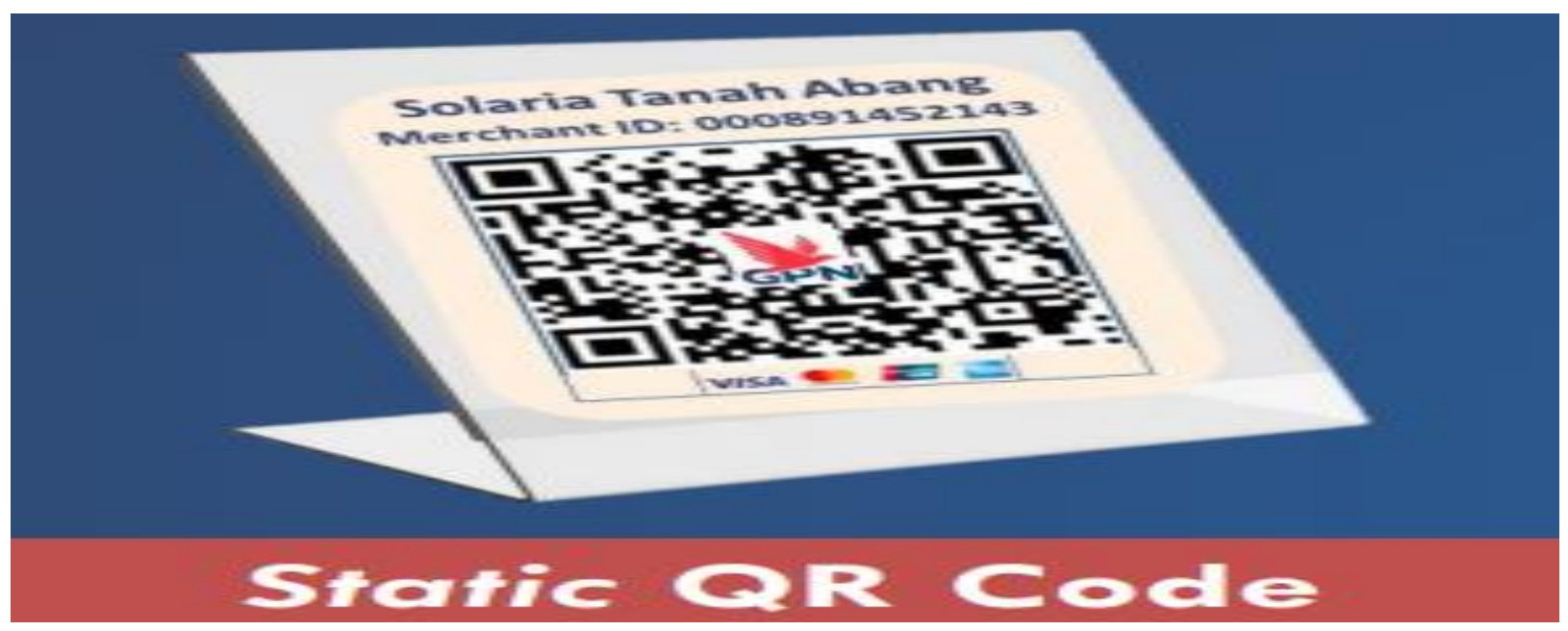

Source ; Bank Indonesia, 2021

Figure 3. Static QR Code

Desy Tri Anggarini 


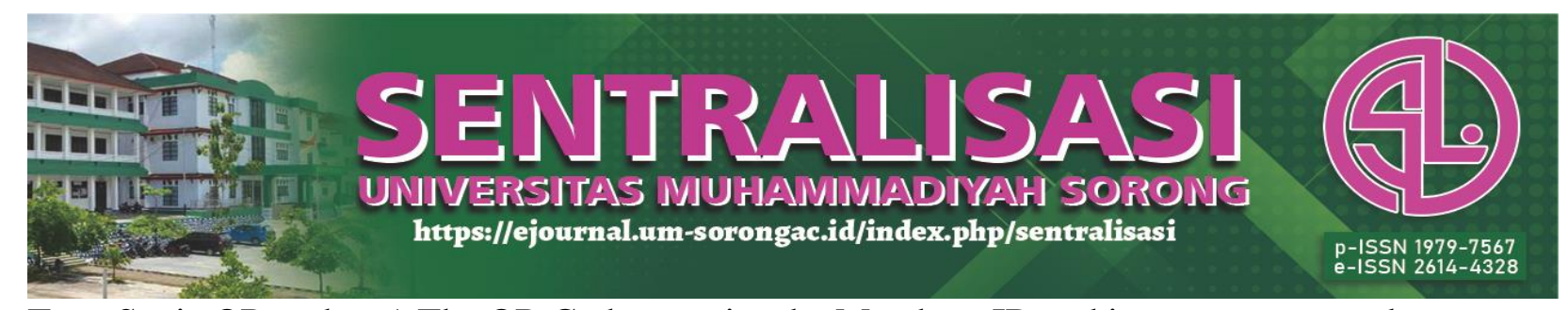

Type Static QR code : a) The QR Code contains the Merchant ID and is permanent, can be displayed on a sticker or print-out so that the QR - code is done once. b) The transaction amount can be inputted by the customer on the customer's mobile device.

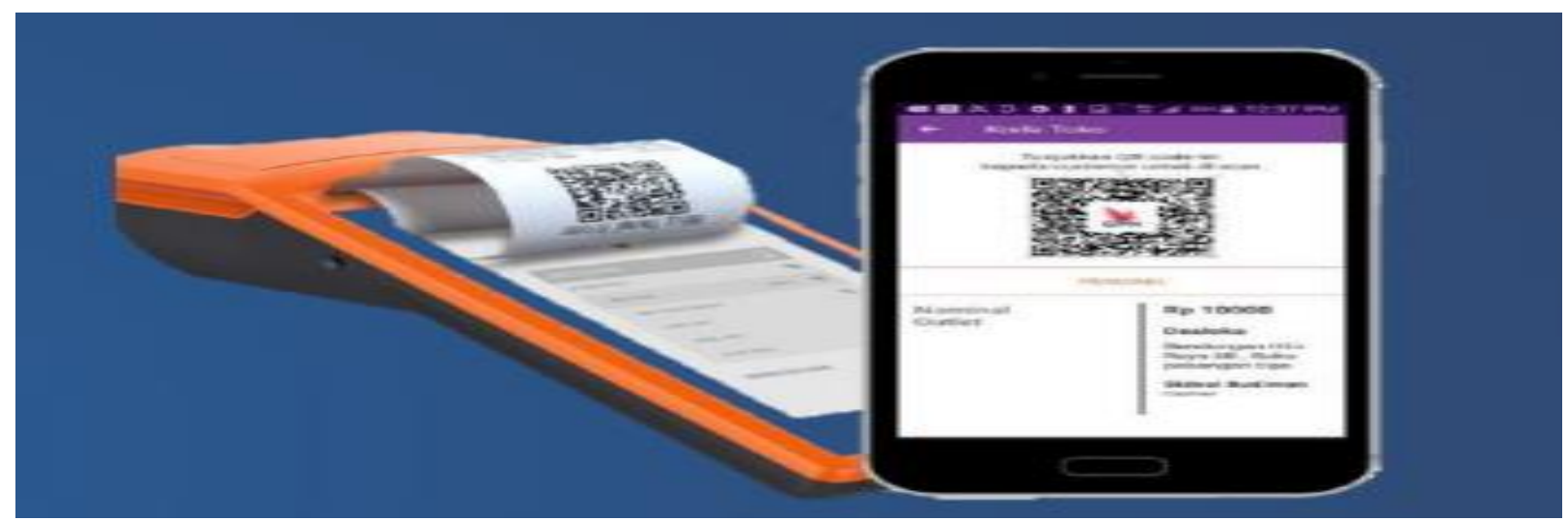

Source ; Bank Indonesia, 2021

Figure 4. Dynamic QR Code

The type of Dynamic QR Code is : a) QR Code is generated in real time at the time of transaction so that the QR Code can be different for each transaction. b) The nominal value of each transaction can be inputted by the merchant. The survey, which was conducted for two months, several consumers using QRIS services prefer to use non-cash services, including Yanti (31 years old) who a vegetable consumer at the BSD Modern Market and always shopping for vegetables every week stated "I have been using OVO for a long time. for transactions, because it's easy to fund, i don't need to carry cash". Since 2021, they used to using barcodes for transactions at several merchants at the BSD Modern Market, such as vegetable, chicken, food and etc.

Consumer Ayu (46 years old) stated "I am used to using digital services by online payments, because it is safer and does not require change," he said. Then Yuni, a student live in Tangerang (20 years old) "I often use QRIS payments because it is fast and easy, all payments are done by phone," he said. Mr. Aliang (26 years old) he stated "I usually use by online payments because ATMs are quite far from the market, so I think it is more practical to use OVO payments, $\mathrm{i}$ always payment it in the chicken merchant and there are so many QR code ".

Tania is a student (21 years old) "I often used to Shopee Pay, because there are many cash back offers from Shoppe Pay, so it's quite economical, from cash back, It can spend again, yes it's quite economical to pay by fintech application. I often shop in traditional markets or just buy drinks in the supermarket," she said. The different statement of Mr. Hanung (26 years old) who a consumer in the BSD modern market, he always uses QRIS. " OVO, Shopee first because the transactions using digital are easier, more practical and most importantly safe, now rarely keep cash in my wallet. Everything do on my cell phone for payment, it's quite practical, isn't it?" he said.

From the side of MSME traders in the BSD Modern Market, Mr. Yuda (34 years old) owner

Desy Tri Anggarini 


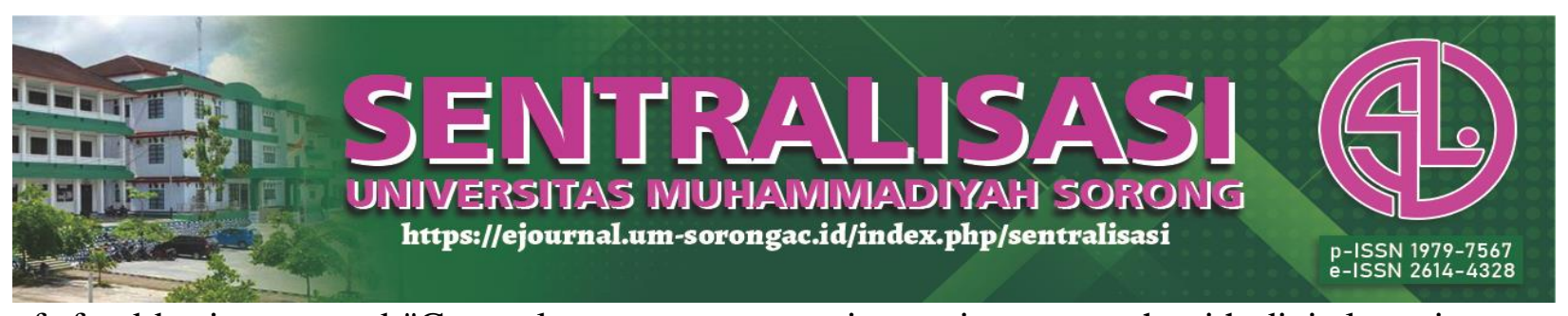

of food business stated "Currently payment transactions using non-cash with digital services are increasing as time by fast, QRIS services exist, since COVID-19, my customers prefer payment non-cash, because they feel safer in terms of cleanliness in accordance with health protocols and indirect contact with cash. " he said. MSME traders frozen food in the BSD modern market, Ms. Ayu (28 years old), the customers mostly use non-cash payments with QRIS "My customers use digital applications, because it's quite easy by Barcodes each transactions, there are services such as OVO, Go pay, Shoppe Pay and others, if previously we had several display links to facilitate all electronic payments, I think it's simpler and more helpful."

MSME trader of fresh sea fish in the modern market of BSD, Mr. Andi (40 years) stated "I have only used the QRIS service for the past year, it is easier for me to monitor daily transaction income, because each application goes directly to my digital wallet, it easier for me to calculate profits." The owner of a clothing shop in the modern market, Lili (25 years) stated that "Customers are mostly using non-cash especially when the corona virus pandemic, many people are reluctant to hold cash, the reason is because they don't want to contact them. directly with other people.

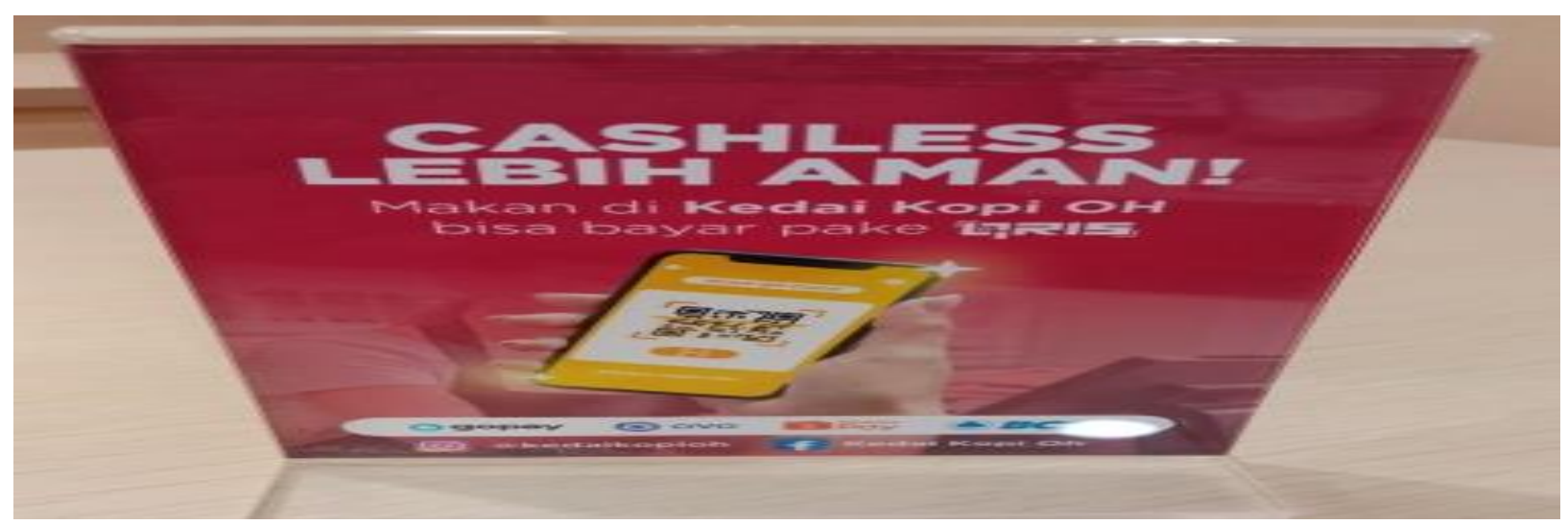

Source: personal documents, 2021

Figure 5. QRIS in merchant

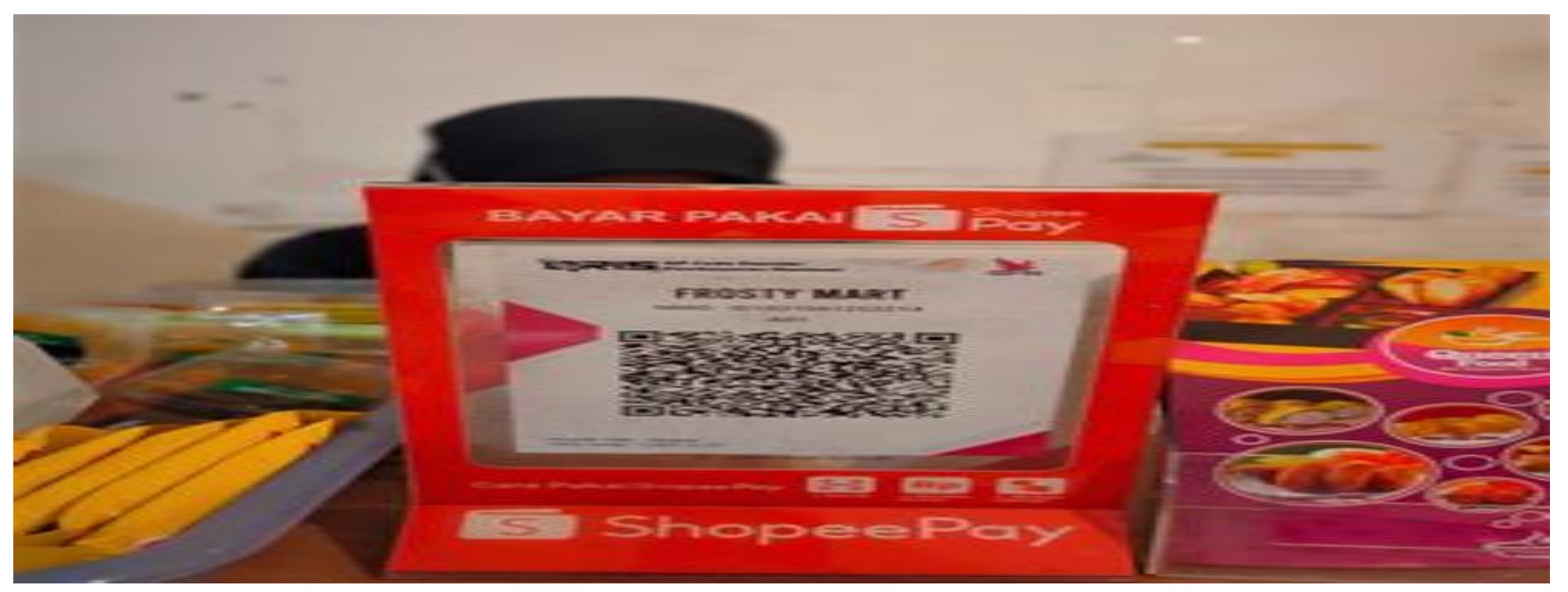

Source: personal documents, 2021

Figure 6. QRIS at the cashier

The results of the research on the application of QRIS (Indonesian Quick Response Code)

Desy Tri Anggarini 


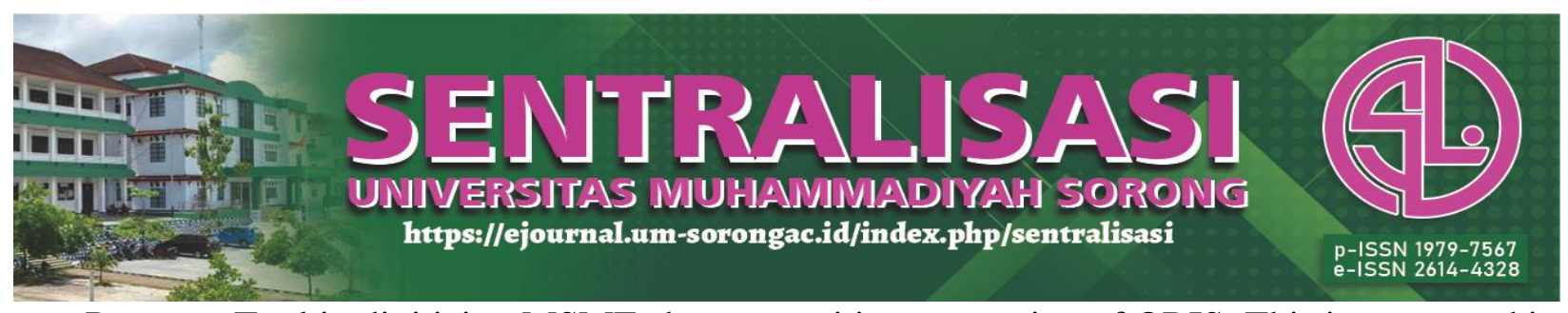

as a Payment Tool in digitizing MSMEs have a positive perception of QRIS. This is expressed in the description of QRIS as a profitable payment tool as a non-cash payment tool that is more hygienic because it reduces direct physical contact with consumers, the shape is simple, easy to use, only places the QRIS barcode in front of the cashier, QRIS accommodates digital transactions by improving service quality., also reduces transaction costs and is more stable.

Barriers to the use of QRIS are network or internet connection constraints, the cost of using QRIS and there is also a limit in non-cash transactions. From the results of surveys and interviews with QRIS, the method of digitizing innovation and technology in the development of innovative payments. MSMEs using QR Codes are a potential in a new era of payment systems, as well as expanding MSME payments in a non-cash way. So that it is more efficient, by using QR Codes, MSME traders in the BSD Modern Market do not need to have various types of QR Codes from various publishers.

How to use QRIS with non-cash transactions by MSME consumers simply use a cellphone that has a camera and is connected to the internet, then a non-cash payment account can be done by downloading a payment application. MSME consumers can register at Payment System Service Providers (PJSP) such as OVO, Shopee pay, Go pay, or e-banking such as BCA, BNI, Bank Mandiri to ensure sufficient balance for transactions, then consumers scan for transactions and enter nominal and confirm payments to SMEs. The advantage that MSME consumers get is that consumers can use an electronic wallet application or mobile banking and pay using QRIS and there are no additional costs.

QRIS can be easily found at MSME traders in BSD modern markets who accept electronic payments through QRIS and Merchants accept payments through QRIS and have the QRIS logo on the stalls of each MSME. With QRIS, MSME consumers in the BSD modern market are facilitated because QRIS can be scanned by all payment applications that have the QR Code feature.

The benefits of QRIS as a digital payment tool for MSMEs include: 1) Follow the payment trend, that are digitally non-cash using Gopay, Ovo, LinkAja, Paytren, Dana, CIMB GoMobile, PermataX, MoBRI, Bank Bali, Shoppe pay. 2) There is a potential for expansion of MSME sales due to alternative payments other than cash. 3) Increasing digital sales traffic and decreasing cash/small cash management costs so that; a. no change required; b. Some of the direct sales money can be deposited in the bank and can be viewed at any time; c. The risk of cash is minimized lost theft decreases. 4) Minimize the risk of loss due to receiving counterfeit money payments. 5) Transactions are recorded automatically and can view transaction history. 6) Building credit profiles for banks, as well as the opportunity to get working capital becomes easier. 7) Payment of retribution, invoices, non-cash purchases of goods easily. 8) Participate in programs held by the government, namely Bank Indonesia, the Ministry of Cooperatives and Small and Medium 


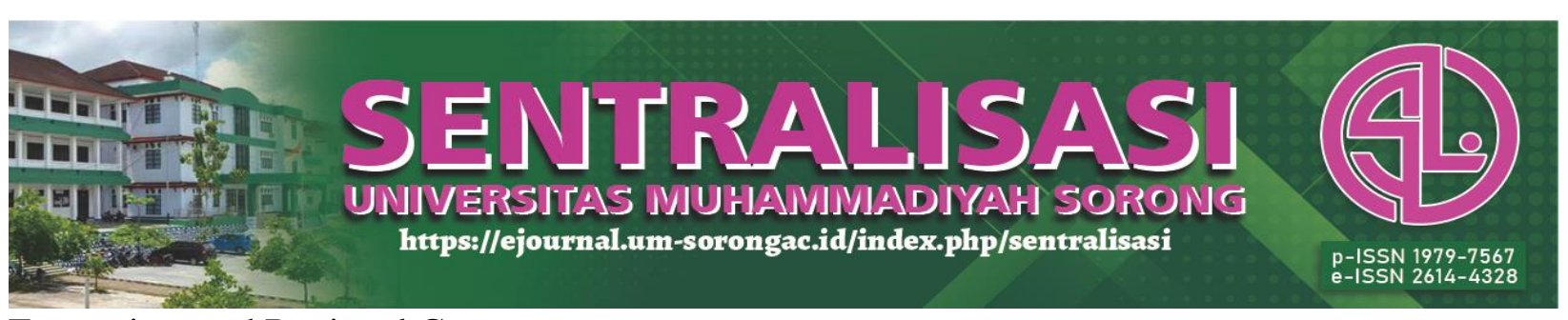

Enterprises and Regional Governments.

The disadvantages of QRIS as a means of payment for MSMEs are: 1) Digital transactions are inseparable from an internet connection. The digital payment method uses QRIS, if the signal is bad, there will be problems with the QR Payment transaction. 2) QRIS transaction failure is generally a bad signal. 3) In addition, despite being a trend for renewable payment methods, They aren't all merchants accept QR Payment as a payment method. 4) Before deal the payment, first make sure the merchant can accept digital payment methods or not.

The Payment System Services/ Jasa Sistem Pembayaran (PJSP) can use QRIS, including (Bank Indonesia, 2021): 1) Banks include Bank Mandiri, BRI, BNI, BCA, CIMB Niaga, BPD, Danamon, BPD Bank, Bank DKI, Bank Nagari, Bank BJB, BPD East Java. Non-banks include OVO, Gopay, Telkom, LinkAja, Dana, Paytren, ShopeePay, BluePay, Artha Gemilang Transactions (Ottocash), DOKU. 2) Switching includes: Alto, Rintis, Jalin, Artajasa. Other Banks include Maybank, Mega, Nobu, Permata Bank, Sinarmas Bank, KEB Hana, OCBC, NISP, UOB. Sharia Banks include Bank Syariah Mandiri and BRI Syaria.

\section{Conclusion}

The development of digital technology currently opens opportunities for MSMEs in improving business performance to contribute to the national economy. One of the industries that survived the pandemic era was MSMEs, which became a new source of strength for the national economy. Bank Indonesia always encourages MSMEs to go digital, as part of the program to increase MSME digitization.

Digitization of payments provides a structural solution for the growth of the electronicsbased industry (e-commerce). Financial technology also encourages the birth of new entrepreneurs. Financial technology encourages the creative industry sector to achieve a wide market distribution.

The application of QRIS (Quick Response Code Indonesian) as a Payment Tool in digitizing MSMEs can improve the Digital Economy and Finance by standardizing the use of QR Codes for non-cash payments to support MSMEs and financial inclusion.

The benefits of QRIS as a digital payment tool for MSMEs of a payment trend, they digitally non-cash using Gopay, Ovo, LinkAja, Paytren, Dana, CIMB GoMobile, PermataX, MoBRI, Bank Bali, Shoppe pay. Expansion of MSME sales and is an alternative payment other than cash. The increase in digital sales leads to a decrease cash/small cash management costs so there is no need for change,

Besides of QRIS can minimize the risk of loss due to payment of counterfeit money. The existence of digital QRIS transactions is recorded automatically every transaction. Opportunities to get capital loan become easier, ease of payment of retribution, bills, purchase of goods non- 


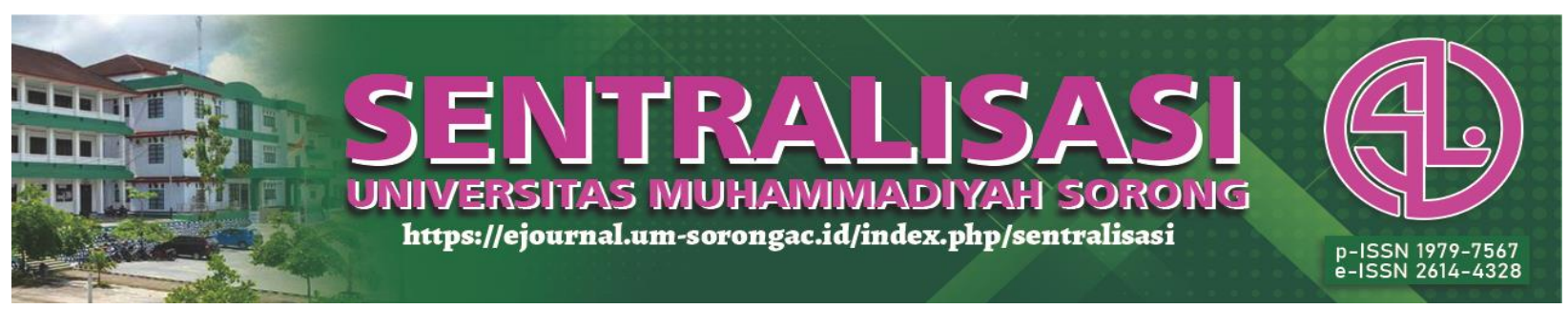

cash easily. It participate programs by the government and Bank Indonesia, the Ministry of Cooperatives and Small and Medium Enterprises and Regional Governments.

On the other hand, the lack of QRIS as a means of payment for MSMEs, among others, is that digital transactions cannot be separated from an internet connection. The digital payment method uses QRIS, if the signal is bad, transaction problems occur. In addition, although there is a trend for renewable payment methods, not all merchants accept QRIS as a payment method, so before making a payment, make sure that the merchant can accept digital payment methods.

\section{Reference}

Arner, DW, B. J. \& B. R. (2015). The evolution of Fintech: A new post-crisis paradigm. Geo. J. Int'l L., 47, 1271.No Title.

Bank Indonesia. (2021a). Empat Kunci UMKM untuk Tembus Pasar Global. https://www.bi.go.id/id/publikasi/ruang-media/news-release/Pages/sp_2324821.aspx

Bank Indonesia. (2021b). Pengembangan Umkm Bank Indonesia. https://www.karyakreatifindonesia.co.id/tentang-kki.

Bank Indonesia. (2021c). QR Code Indonesian Standard (QRIS) Apa Itu QRIS? https://www.bi.go.id/QRIS/default.aspx

Bungin, B. (2011). Metodologi Penelitian Kualitatif. Raja Grafindo Persada.

Dalimunthe, M. (2018). Implememtasi Fintech Terhadap UMKM Di Kota Medan Dengan Analisis Swot. Journal of Chemical Information and Modeling. Journal of Chemical Information and Modeling, 53(9), 1689-1699. Https://Doi.Org/10.1017/CBO9781107415324.0.

Darma, W., \& others. (2018). I. D. I. D. P. (n.d.). Inovasi Diskruptif(Disruptive Innovation) Dalam Pendidikan.

Gabriella Mulligan. (2015). “African banks and fintech startups -an ideal match?”AfricanBanker 4th Quarter 2015,. AfricanBanker 4th Quarter 2015, Pg 33-35.

Hasan, H. A. (2020). DAMPAK TEKNOLOGI DALAM TRANSAKSI BISNIS UMKM. JURNAL PILAR: Jurnal Kajian Islam Kontemporer Tahun 20202 ISSN: 1978-5119 Universitas Muhammadiyah Makassar, Indonesia., Volume 11.

Hiyanti, Nugroho L, Sukmadilaga C, F., \& T. (2020). Peluang dan Tantangan Fintech (Financial Technology) Syariah di Indonesia. Jurnal Ilmiah Ekonomi Islam, 5(3), 326-333.

Kementrian Koperasi dan UKM. (2021). No Title. Kementrian Koperasi Dan UKM. https://kemenkopukm.go.id/read/ma-ruf-ingin-percepatan-digitalisasi-umkm-dilakukanmaksimal) Revisi ke-3 


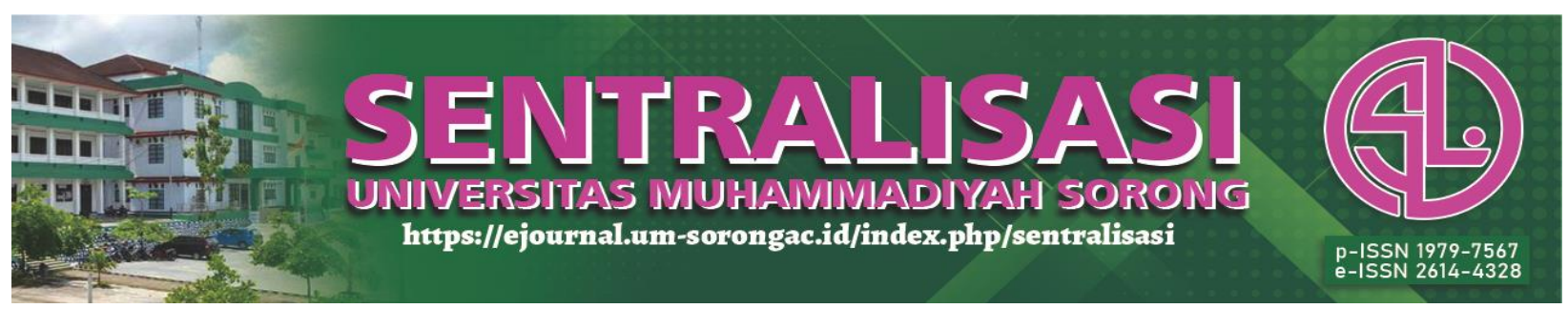

Sugiono. (2019). Metode Penelitian Kuantitatif. Yogyakarta: Bayu Indra Grafika.

Sugiyono. (2010). Metode Penelitian Pendidikan Pendekatan Kualitatif, Kuantitatif dan $R$ \& D. Bandung :Alfabeta.

Wulandari, P. A. (2017). Analisis SWOT Perkembangan Finansial Teknologi Di Indonesia. Proceeding of National Conference on Asbis, 2(1), 376-383.

Yarli, D. (2018). Analisis Akad Tijarah pada Transaksi Fintech Syariah dengan Pendekatan Maqhasid. YUDISIA: Jurnal Pemikiran Hukum Dan Hukum Islam,9(2\}. 